\title{
Does the Benthos Control Phytoplankton Biomass in South San Francisco Bay?
}

\author{
James E. Cloern \\ U.S. Geological Survey, 345 Middlefield Road, MS 96, Menlo Park, California 94025, USA
}

\begin{abstract}
South San Francisco Bay, USA, is a shallow coastal embayment that receives large inputs of nutrients (N, $P, S i)$ and small local inputs of freshwater. Phytoplankton dynamics are typically characterized by a spring bloom when surface chlorophyll a increases from $<5$ to $>40 \mathrm{mg} \mathrm{m}^{-3}$. The bloom persists for 2 to $4 \mathrm{wk}$, and then dissipates. Phytoplankton biomass remains low (chlorophyll $a$ $<5 \mathrm{mg} \mathrm{m}^{-3}$ ) from May through December, although light and nutrient availability are sufficient to sustain growth rates of 1 to 1.5 divisions $\mathrm{d}^{-1}$ in the expansive shallows. Transport processes apparently exert a small influence on phytoplankton biomass, and calculated zooplankton grazing accounts for only a small reduction in net rate of phytoplankton population growth in the shallows. However, suspension-feeding bivalves are sufficiently abundant to filter a volume equivalent to the volume of South Bay at least once daily. These observations suggest that grazing by benthos is the primary mechanism controlling phytoplankton biomass during summer and fall.
\end{abstract}

\section{INTRODUCTION}

Because urbanized estuaries and nearshore coastal waters are used as receiving waters for municipal wastes, they often support high biomass of planktonic algae. Concentrations of chlorophyll a often exceed $20 \mathrm{mg} \mathrm{m}^{-3}$ and may exceed $100 \mathrm{mg} \mathrm{m}^{-3}$ in temperate estuaries during summer (Ketchum, 1970). Examples include the Chesapeake Bay and associated estuaries (Carpenter et al., 1970; Flemer, 1972; Loftus et al., 1972; Van Valkenberg and Flemer, 1974), Narrangansett Bay (Kremer and Nixon, 1978), Pamlico River (Hobbie et al., 1972), lower New York Bight (Parker et al., 1976), Long Island Sound (Riley, 1941), Kiel Bight (Lenz, 1977), Tokyo Bay (Ichimura, 1967), and northern San Francisco Bay (Cloern, 1979). In some cases, nutrient enrichment has caused overt eutrophication with algal blooms and subsequent depletions of dissolved oxygen (e. g. Chesapeake Bay: Shubel and Cronin, 1977; Heinle et al., 1979; Potomac River estuary: Jaworski et al., 1972; New York Bight: Segar and Berberian, 1976).

South San Francisco Bay is a shallow estuary that receives effluent from 20 municipal sewage treatment plants discharging $1.3 \mathrm{~km}^{3}$ of wastewater annually (South Bay volume is $2.5 \mathrm{~km}^{3}$ : Conomos et al., 1979). Nutrient concentrations usually exceed levels that limit phytoplankton growth: dissolved inorganic nitrogen exceeds $20 \mu \mathrm{M}$, dissolved phosphate exceeds $5 \mu \mathrm{M}$, and dissolved silica exceeds $50 \mu \mathrm{M}$ in surface waters of the central channel of South Bay (Conomos et al., 1979). Although the southern extremity of South Bay occasionally experiences short-term and localized depressions of dissolved oxygen (Cloem and Oremland, 1982), this nutrient-enriched estuary does not exhibit symptoms of eutrophication. In fact, phytoplankton biomass is usually low: chlorophyll a concentration typically is static and less than $5 \mathrm{mg} \mathrm{m}^{-3}$ during summer (Cloern, 1979). The absence of algal blooms in South San Francisco Bay is unexpected and is the subject of this paper.

The South Bay (Fig. 1) is a coastal embayment having large expanses of shallows $(\bar{z} \simeq 2 \mathrm{~m})$ and a narrow central channel $(\bar{z} \simeq 10 \mathrm{~m})$. Local tributaries usually have low discharge $\left(0.1 \mathrm{~km}^{3} \mathrm{yr}^{-1}\right.$ : Conomos et al., 1979) and the South Bay is vertically well-mixed throughout most of the year. Exceptions occur periodically in the winter or spring when discharge of the Sacramento River is high and freshwater intrudes from northern San Francisco Bay, or during periods of heavy rainfall when local runoff provides sufficient freshwater to induce salinity stratification. Material transport is effected primarily by tidal mixing and tidal and residual (tidally-ayeraged) cirçulation. Numerical 


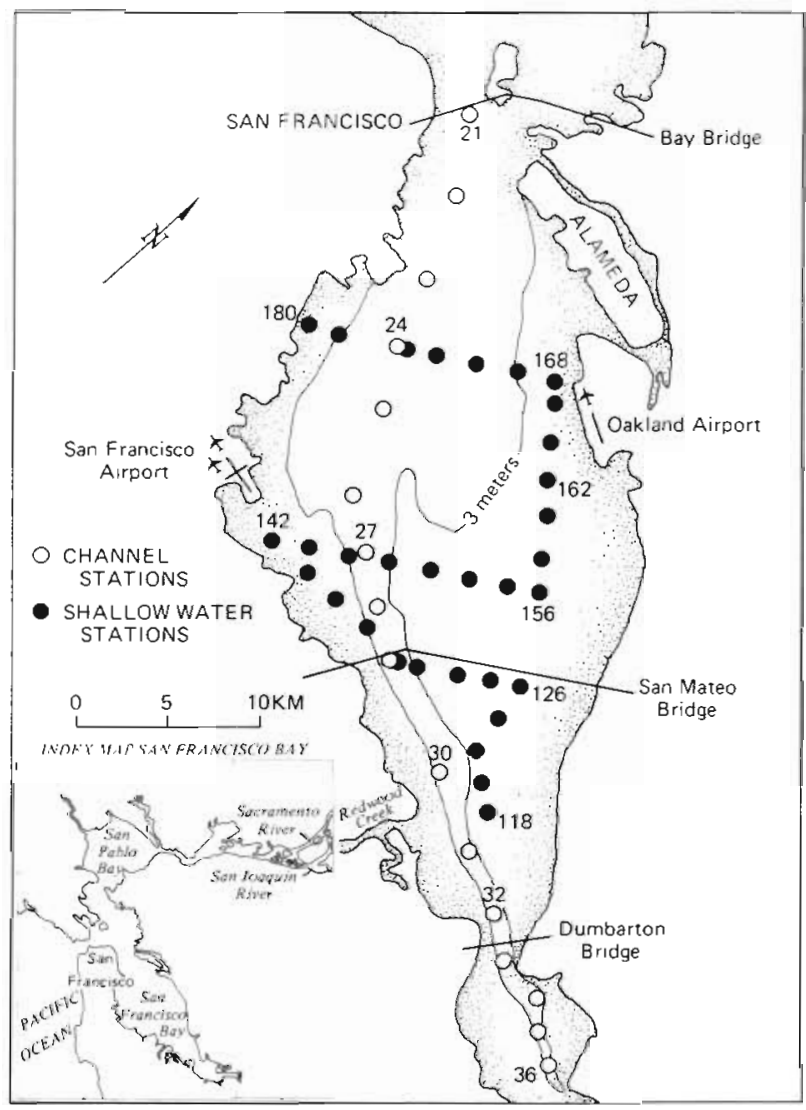

Fig. 1. Map of South San Francisco Bay showing locations of sampling sites in the channel (Stations 21 to 36) and across the shoals (Stations 118 to 180 )

models suggest that large scale circulation is characterized by a counterclockwise gyre having nontidal currents that flow southerly in the channel and northerly over the eastern shoals at a velocity of several centimeters per second (Walters and Cheng, 1980). This general circulation is presumably modulated by seasonal changes in wind stress and perhaps by gravitational circulation in the channel during periods of stratification (Walters, 1982). Hydraulic residence time is several months in summer (Conomos, 1979).

Here I present results of a biological sampling program conducted in the South Bay throughout 1980, and then present an analysis of processes thought to govern phytoplankton population dynamics. Initial hypotheses are that phytoplankton biomass is regulated by three processes (specific growth rate, transport, and zooplankton grazing), and that transport losses and losses to herbivorous zooplankton balance the specific growth rate during the summer period of zero population growth. A simple model is used to test this hypothesis by estimating the magnitude of each process throughout 1980 . As will be seen, estimated losses do not balance the estimated rate of population growth, and an additional loss term is required for this balance. Preliminary calculations suggest that benthic suspension feeders filter a sufficient volume of water daily to consume all algal production, and benthic grazing may be the process accounting for the unexplained loss of phytoplankton biomass. Separate analyses are done for the channel and eastern shallows (Fig. 1), where rates of individual processes differ.

\section{METHODS}

\section{Field Program}

The sampling program was designed to measure phytoplankton biomass and primary production, zooplankton biomass, turbidity, salinity, and temperature along the central channel and across the shoals of South Bay. Sampling was conducted from 2 vessels, one which obtained continuous surface profiles (invivo fluorescence, turbidity, salinity, temperature), and vertical profiles at 6 sites, along the channel (Stations 36 to 21, Fig. 1), while the other vessel profiled surface waters over the shoals (Stations 118 to 180 ).

Chlorophyll a was estimated from in-vivo fluorescense; fluorometers were calibrated each cruise against measured chlorophyll $a$ in surface samples collected at 6 to 7 key sites (numbered stations, Fig. 1). Discrete samples were filtered onto glass fiber filters then ground and extracted in $90 \%$ acetone. The equations of Lorenzen (1967) were used to calculate chlorophyll $a$ and phaeopigment concentrations.

Turbidity was measured with nephelometers that were calibrated each cruise against extinction coefficient $\varepsilon$, which was measured at all key sites. Vertical extinction of photosynthetically available radiation (PAR) was measured with LiCor 192S quantum sensors. Salinity was measured with induction salinometers, temperature with thermistors (Schemel and Dedini, 1979). Daily insolation (PAR) was measured at Redwood Creek with a LiCor 190 quantum sensor and integrator

Previous studies of phytoplankton species composition (Wong and Cloern, 1981) and chlorophyll distribution (Alpine et al., 1981) showed that (1) community composition in South Bay is not spatially heterogeneous (i.e. the phytoplankton community over the shoals is usually dominated numerically by the same species which dominate along the central channel); (2) horizontal chlorophyll gradients are higher between the channel and shoals than along the north-south axes of the channel or shoals. From these past studies, 2 sites were picked to represent the phytoplankton population of the channel (Station 27) and the eastern shoals (Station 156 or 162). At these sites, phytoplankton 
samples were collected and preserved in Lugol's solution with $10 \%$ acetate. From each sample, 3 aliquots were examined under an inverted microscope both at $80 \times$ and $1000 \times$. Algal cells were identified to species and enumerated, and total biovolume was calculated from measured cell dimensions. Phytoplankton biomass as carbon was estimated from the equations of Strathmann (1967), thus allowing calculation of the phytoplankton carbon: chlorophyll ratio. At these same 2 sites, surface samples were collected monthly for determination of photosynthetic carbon assimilation by phytoplankton (Cole et al., 1982). Subsamples were placed in $125-\mathrm{ml}$ bottles and incubated with ${ }^{14} \mathrm{C}$ for $24 \mathrm{~h}$ in a water-cooled deck box receiving natural illumination. Irradiance was attenuated with 7 neutral screens of different mesh density (transmittance was between about $1 \%$ and $50 \%$ ambient sunlight). On 6 dates, samples were collected at 5 additional stations in the channel and 4 stations over the shoals and then incubated with ${ }^{14} \mathrm{C}$ at about $50 \%$ full sunlight. This provided an estimate of the spatial variation in maximum assimilation rate.

Zooplankton were collected at all key sites by pumping into a $64-\mu \mathrm{m}$ mesh net (pump specifications are from Peterson et al., 1979). Three depths were sampled in the channel and one mid-depth sample was collected at shoal sites. Abundance was estimated by identifying and enumerating animals in aliquots from each sample. Total zooplankton biomass as carbon was estimated from abundances and assumed constant car- bon quotas ( $\mathrm{mg} \mathrm{C}$ animal ${ }^{-1}$ ) of all organisms enumerated. Individual carbon quotas were either measured with a CHN analyzer or were estimated from values reported in the literature (Hutchinson, 1981).

\section{Calculation of Process Rates}

The one-dimensional dispersion equation was used as a framework to calculate net rates of phytoplankton population growth (all symbols and units are given in Table 1):

$$
\begin{aligned}
& \frac{\partial C L}{\partial t}=\frac{1}{A} \frac{\partial}{\partial x}\left(D A \frac{\partial C L}{\partial x}\right)+\mu C L-G C L \\
& \text { Net rate of }=\text { Dispersive } \quad+\text { Growth }- \text { Zooplankton } \\
& \text { population transport grazing }
\end{aligned}
$$
change

This equation approximates the net rate of phytoplankton population growth if the following assumptions hold: (1) vertical variations in biomass are small compared to longitudinal variations; (2) over time scales of days to weeks, transport (including tidal mixing and tidal circulation) can be treated as a dispersive process; (3) residual circulation (nontidal advection) is slow relative to dispersion; (4) lateral (east-west) transport is slow compared to longitudinal (north-south) transport; (5) dispersion coefficient $D$ is constant. The magnitude of each term of Equation 1 was calculated to estimate net rate of population change on each

\begin{tabular}{|c|c|c|}
\hline Variable & Definition & Units \\
\hline $\mathrm{CL}$ & Chlorophyll a concentration & $\mathrm{mg} \operatorname{chl} a \mathrm{~m}^{-3}$ \\
\hline t & Time & d \\
\hline A & Cross sectional area & $\mathrm{km}^{2}$ \\
\hline $\mathrm{x}$ & Longitudinal coordinate (distance) & $\mathrm{km}$ \\
\hline $\mathrm{D}$ & Longitudinal dispersion coefficient & $\mathrm{km}^{2} \mathrm{~d}^{-1}$ \\
\hline$\mu$ & Specific growth rate of phytoplankton & $d^{-1}$ \\
\hline $\mathrm{G}_{2}$ & Specific grazing rate of zooplankton & $d^{-1}$ \\
\hline $\mathrm{P}^{\mathrm{B}}$ & Biomass-specific carbon assimilation rate & $\mathrm{mgC} \mathrm{mg}{ }^{-1} \operatorname{chl~ad^{-1}}$ \\
\hline $\mathrm{P}_{M}^{\mathrm{B}}$ & Maximum carbon assimilation rate & $\mathrm{mg} \mathrm{C} \mathrm{mg}{ }^{-1} \mathrm{chl} \mathrm{ad}^{-1}$ \\
\hline$a^{M}$ & Parameter of photosynthesis-irradiance curve & $\mathrm{m}^{2} \mathrm{~d} /$ Einstein \\
\hline I & Photosynthetically available radiance & Einsteins $\mathrm{m}^{-2} \mathrm{~d}^{-1}$ \\
\hline$r^{B}$ & Biomass-specific respiration rate & $\mathrm{mgC} \mathrm{mg}^{-1} \mathrm{chl} a \mathrm{~d}^{-1}$ \\
\hline $\int \mathrm{P}$ & Depth-integrated net productivity & $m g C m^{-2} d^{-1}$ \\
\hline $\mathrm{P}$ & Net productivity per unit volume & $\mathrm{mgC} \mathrm{m}-3 \mathrm{~d}^{-1}$ \\
\hline $\mathrm{z}$ & Vertical coordinate (depth) & $\mathrm{m}$ \\
\hline $\mathrm{H}$ & Water-column depth & $\mathrm{m}$ \\
\hline$\varepsilon$ & Light extinction coefficient & $\mathrm{m}^{-1}$ \\
\hline $\mathrm{C}$ & Phytoplankton biomass as carbon & $\mathrm{mg} \mathrm{C} \mathrm{m} \mathrm{m}^{-3}$ \\
\hline $\mathrm{Z}$ & Zooplankton biomass as carbon & $\mathrm{mgC} \mathrm{m}^{-3}$ \\
\hline$\delta$ & Parameter of zooplankton ingestion curve & $\mathrm{m}^{3} \mathrm{mg}^{-1} \mathrm{C}$ \\
\hline $\mathrm{T}$ & Temperature & degrees C \\
\hline W & Body weight of animals & $\begin{array}{l}\text { g C animal }{ }^{-1} \text { for zooplankton } \\
\text { g dry wt animal }{ }^{-1} \text { for bivalves }\end{array}$ \\
\hline $\mathrm{F}$ & Filtration rate of bivalves & 1 animal $^{-1} \mathrm{~d}^{-1}$ \\
\hline
\end{tabular}
sampling date of 1980. Transport rate (dispersive flux)

Table 1. Definitions of variables (and their units) discussed in the text 
was calculated from observed distributions of chlorophyll and an assumed value for $D$, specific growth rate was calculated from primary productivity, and zooplankton grazing rate was calculated from measured zooplankton biomass and published inges-

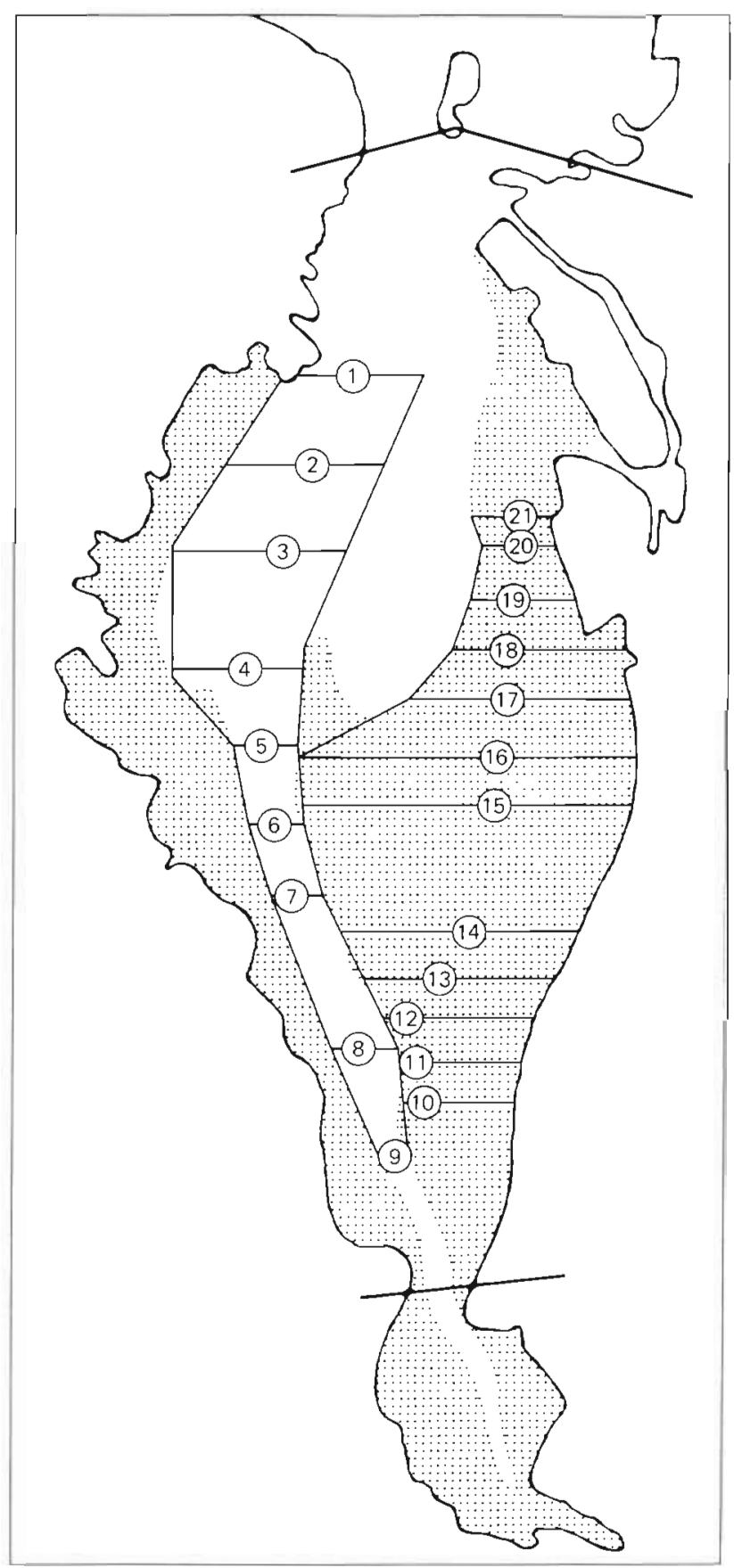

Fig. 2. Geometric approximation of the channel and eastern shoals of South Bay for calculating dispersive flux of chlorophyll (Equation 2). Chlorophyll was measured at all nodes (circles), where channel nodes (1 to 9) correspond to Stations 23 to 31 and shoal nodes (10 to 21) correspond to Stations 118 to 126 and 156 to 168 tion rates. This analysis was done separately for channel sites in the main body of South Bay (Stations 23 to 31) and for sampling sites along the eastern shoals of South Bay (Stations 118 to 126, 126 to 156, and 156 to 170).

Transport Rate. Glenne and Selleck (1969) used the one-dimensional tidally-averaged advectiondispersion equation to calculate dispersion coefficients in the South Bay channel, using chloride and silica as tracers. Their estimates ranged from about $2 \times 10^{5}$ to 1 $\times 10^{6} \mathrm{~cm}^{2} \mathrm{~s}^{-1}$. Fischer and Kirkland (1978) treated transport as a bulk exchange process to describe the distribution of dye in a physical model of South Bay. Their estimated exchange coefficients were equivalent to dispersion coefficients that ranged from $4.5 \times 10^{5}$ to $1.8 \times 10^{6} \mathrm{~cm}^{2} \mathrm{~s}^{-1}$. Here I use a constant value of $\mathrm{D}=$ $10^{6} \mathrm{~cm}^{2} \mathrm{~s}^{-1}\left(=8.6 \mathrm{~km}^{2} \mathrm{~d}^{-1}\right)$ to represent dispersion along the north-south axes of the channel and shoals.

The transport rate of phytoplankton biomass was estimated by first calculating the dispersive flux of chlorophyll at 7 sample sites (nodes) in the channel and 10 sites in the shoals, using a finite difference approximation:

Dispersive Flux (mg chlorophyll $\mathrm{m}^{-3} \mathrm{~d}^{-1}$ ) $=$

$J_{i}=\frac{2 D}{A_{i}}\left[\frac{A_{i+1 / 2}\left(\frac{C L_{i+1}-C L_{1}}{x_{i+1}-x_{i}}\right)-A_{\lambda-1 / 2}\left(\frac{C L_{i}-C L_{i-1}}{x_{i}-x_{1-1}}\right)}{x_{l+1}-x_{i-1}}\right]$

where $C L_{1}=$ chlorophyll concentration at node $i_{;} x_{i}=$ distance $(\mathrm{km})$ of node $i$ from Node 1 (for the channel) or Node 10 (for the shoals; see Fig. 2); $A_{i}=$ cross-sectional area $\left(\mathrm{km}^{2}\right)$ after partitioning the channel and eastern shoals into 2 segmented reaches (Fig. 2). Then, the dispersive flux $\left(J_{\nu}\right)$ of chlorophyll at each node was normalized by chlorophyll concentration ( $C L$, ) to give a biomass-specific rate of transport; mean values of the derived parameter $J_{f} / C L_{1}$ were calculated for the channel and eastern shoals:

Transport rate in the channel $\left(\mathrm{d}^{-1}\right)=$

$$
\frac{1}{7} \sum_{i=2}^{8} J_{i} / C L_{1}
$$

Transport rate in the shoals $\left(\mathrm{d}^{-1}\right)=$

$$
\frac{1}{10} \sum_{i=11}^{20} J_{i} / C L_{i}
$$

Note that this measure of transport rate represents a mean specific rate of biomass change (or turnover rate) resulting from dispersion, and has units equivalent to specific growth rate. 
Growth Rate. Specific growth rate was calculated from productivity versus irradiance ( $P$ vs $I$ ) curves. First, daily carbon assimilation rate was fit by least squares to the hyperbolic tangent function of daily irradiance (Jassby and Platt, 1976; Chalker, 1980):

$P^{B}=P_{M}^{B} \tanh (a I)-r^{B}=P_{M}^{B}\left(\frac{e^{2 a I}-1}{e^{2 a I}+1}\right)-I^{B}$

Separate fits were obtained for the channel and shoal samples unless slopes of the linear portions of the $P$ vs. $I$ curves were not significantly different. In that case, the photosynthetic parameters $\left(P_{M^{\prime}}^{B} a, r^{B}\right)$ were estimated from fits to pooled data from both sites (e.g. Fig. 3). Values of $P_{M}^{B}$ for the channel and shoal populations always agreed within $10 \%$ of their mean when

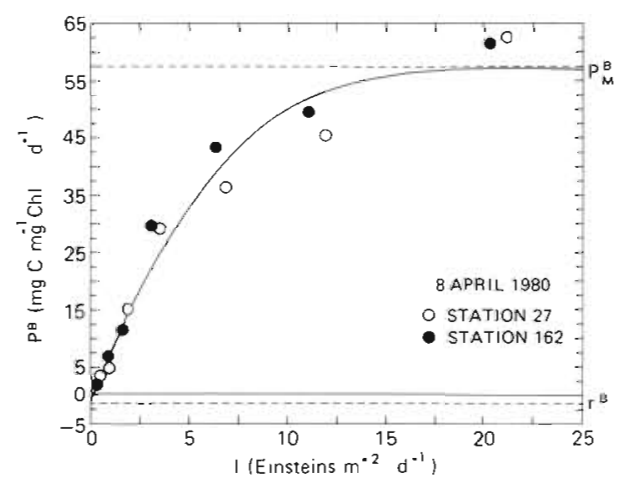

Fig. 3. Representative fit of Equation 5 to measured daily carbon assimilation rate at 7 light intensities. Equation 5 was fit here to pooled data from one sample collected in the channel and one sample from the eastern shoals

values of $a$ were not significantly different (i. e. $P_{M}^{B}$ was never different between the populations unless $a$ was different: Cole et al., 1982). Respiration rate $r^{B}$ ranged between $3 \%$ and $10 \%$ of $P_{M}^{B}$ and averaged $5 \%$ of $P_{M}^{B}$ (Cole et al., 1982). To calculate growth rate, $I^{B}$ was fixed as $0.05 P_{M}^{B}$. For those sampling periods when primary productivity was not measured, $P_{M}^{B}$ and a were estimated from linear interpolations of values measured on previous and subsequent sampling dates.

Assuming that single measurements of photosynthetic parameters were representative of the phytoplankton community in the channel and shoals (see below), net depth-integrated productivity $\left(\int P\right)$ and specific growth rate $(\mu)$ were calculated at each of the 9 channel and 12 shoal sites (Fig. 2):

$\int P_{i}\left(\mathrm{mgC} \mathrm{m} \mathrm{d}^{-2}\right)=C L_{\perp} \int_{0}^{H_{i}}\left\{P_{M}^{B} \tanh \left(a I_{z}\right)-r^{B}\right\} d z$

where $H_{j}=\operatorname{depth}(\mathrm{m})$ of Site $i$ at mean tide level; $I_{z}=$ insolation (PAR) at depth $z$ :

$$
I_{z}=I_{o} e^{-\varepsilon z}
$$

Surface insolation $I_{0}$ was taken as the weekly mean irradiance at Redwood Creek prior to sampling. Equation 6 was integrated numerically and divided by depth to give mean daily carbon assimilation per unit volume $\left(P_{i}=\int P_{1} / H_{1}\right)$. Use of Equation 6 assumes no vertical variation in photosynthetic parameters, carbon : chlorophyll a ratio, or biomass of phytoplankton. On the few dates when the channel was stratified, Equation 6 was integrated from the surface to the depth of the pyncnocline, and $C L_{i}$ was set equal to mean chlorophyll concentration in the surface layer. This value of $\int P$ was then adjusted for respiration in the bottom layer using the measured value of $r^{B}$ from the surface sample and mean chlorophyll concentration below the pyncnocline. Specific growth rate was calculated as:

$$
\mu_{1}\left(\mathrm{~d}^{-1}\right)=\ln \left[\frac{P_{1}+C_{2}}{C_{i}}\right]
$$

Phytoplankton biomass as carbon $\left(C_{j}\right)$ was estimated from chlorophyll a concentration, assuming a constant ratio of phytoplankton carbon: chlorophyll $a=49$. This value was the mean ( $\mathrm{s}=29$ ) of 41 estimates; the paired t-test showed no significant difference in $\mathrm{C}: \mathrm{Cl}$ between the channel and shoal populations. Mean values of $\mu$ were calculated separately for the channel and shoals.

Zooplankton Grazing. Total zooplankton biomass was partitioned into 5 compartments: Acartia adults $\left(Z_{a}\right)$, Acartia copepodites $\left(Z_{d}\right)$, Acartia nauplii $\left(Z_{n}\right)$, tintinnid ciliates $\left(Z_{\downarrow}\right)$, and other zooplankton $\left(Z_{\alpha}\right)$. Phytoplankton ingestion by the 3 stages of the dominant copepod Acartia was calculated from an Ivlev curve (Parsons and LeBrasseur, 1970), modified such that maximum ingestion rate varies with body size (W) and temperature $(T)$ :

$$
\begin{aligned}
& G_{a, c, n}\left(\mathrm{mg} \mathrm{C} \mathrm{mg}^{-1} \mathrm{C} \mathrm{d}^{-1}\right)= \\
& \frac{0.95 W^{0.8}}{\text { Body size }} \frac{e^{0.069(T-10)}}{\text { Temperature Food concentration }} \frac{\left(1-\mathrm{e}^{-\delta C}\right)}{}
\end{aligned}
$$

Feeding studies have shown with some consistency that ingestion rate of calanoid copepods attains a maximum when food concentration reaches about $300 \mathrm{mg}$ $\mathrm{C} \mathrm{II}^{-3}$ (Mullin and Brooks, 1967; Frost, 1972; Harris and Paffenhöfer, 1976; Gamble, 1978). The parameter $\delta$ was fixed at 0.01 , such that ingestion rate is $96 \%$ of maximum when $\mathrm{C}=300$. The few existing studies of temperature effects on copepod feeding (e.g. Conover, 1956; Ikeda, 1974; Vidal, 1980) suggest that ingestion rate doubles from $10^{\circ} \mathrm{C}$ (winter temperature in South Bay) to $20^{\circ} \mathrm{C}$ (maximum summer temperature in South Bay). Weight-specific ingestion of copepods decreases with body size, and appears to be an allometric function of body size with a coefficient of about 0.8 
(Paffenhöfer, 1971; Nival and Nival, 1976; Vidal, 1980). The constant 0.95 was picked so that individual Acartia adults ingest 1.5 times their body weight $\left(2.9 \mu \mathrm{g} \mathrm{C}\right.$ animal ${ }^{-1}$ : Hutchinson, 1981), copepodites ingest 2 times their weight $(0.8 \mu \mathrm{g} \mathrm{C})$, and nauplii ingest 3 times their weight $(0.1 \mu \mathrm{g} \mathrm{C})$ daily at $20^{\circ} \mathrm{C}$. These maximum ingestion rates are at the upper limit of most measured ingestion rates (Hargrave and Geen, 1970; Paffenhöfer, 1971; Harris and Paffenhöfer, 1976; Paffenhöfer and Knowles, 1978).

Tintinnids were assumed to ingest 3 times their weight daily (i,e. $G_{t}=3$ ), and ingestion by other zooplankton was approximated with a simple Ivlev curve where maximum ingestion rate $=1 \mathrm{mg} \mathrm{C} \mathrm{mg}^{-1}$ $\mathrm{Cd}^{-1}$ :

$$
G_{0}=\left(1-e^{-0.01 c}\right)
$$

Specific phytoplankton loss rate from zooplankton grazing was then calculated at all sites where zooplankton were collected:

$$
G_{z}\left(\mathrm{~d}^{-1}\right)=\frac{G_{a} Z_{a}+G_{c} Z_{c}+G_{n} Z_{n}+G_{t} Z_{t}+G_{o} Z_{o}}{C}
$$

\section{RESULTS}

From January through March, chlorophyll a concentration in South Bay was usually less than $2 \mathrm{mg} \mathrm{m}^{-3}$, except over the eastern shoals where, at times, chlorophyll a approached $10 \mathrm{mg} \mathrm{m}^{-3}$. During early April chlorophyll a increased rapidly and approached $50 \mathrm{mg} \mathrm{m}^{-3}$ in the southern half of South Bay (Fig. 4). By late April this bloom dissipated, and from May through December chlorophyll a concentration was consistently less than $10 \mathrm{mg} \mathrm{m}^{-3}$ (usually $<5 \mathrm{mg} \mathrm{m}^{-3}$ throughout South Bay). Vertical contours of salinity and chlorophyll in the channel (e. g. Fig. 5) show that the April bloom occurred during the period of maximum salinity stratification and that high chlorophyll

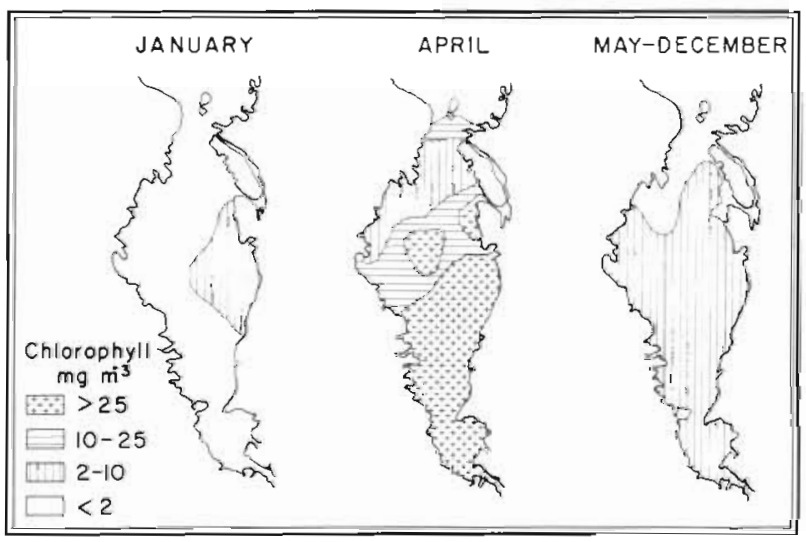

Fig. 4. Surface contours of chlorophyll a during winter, during spring bloom, and following spring bloom of 1980
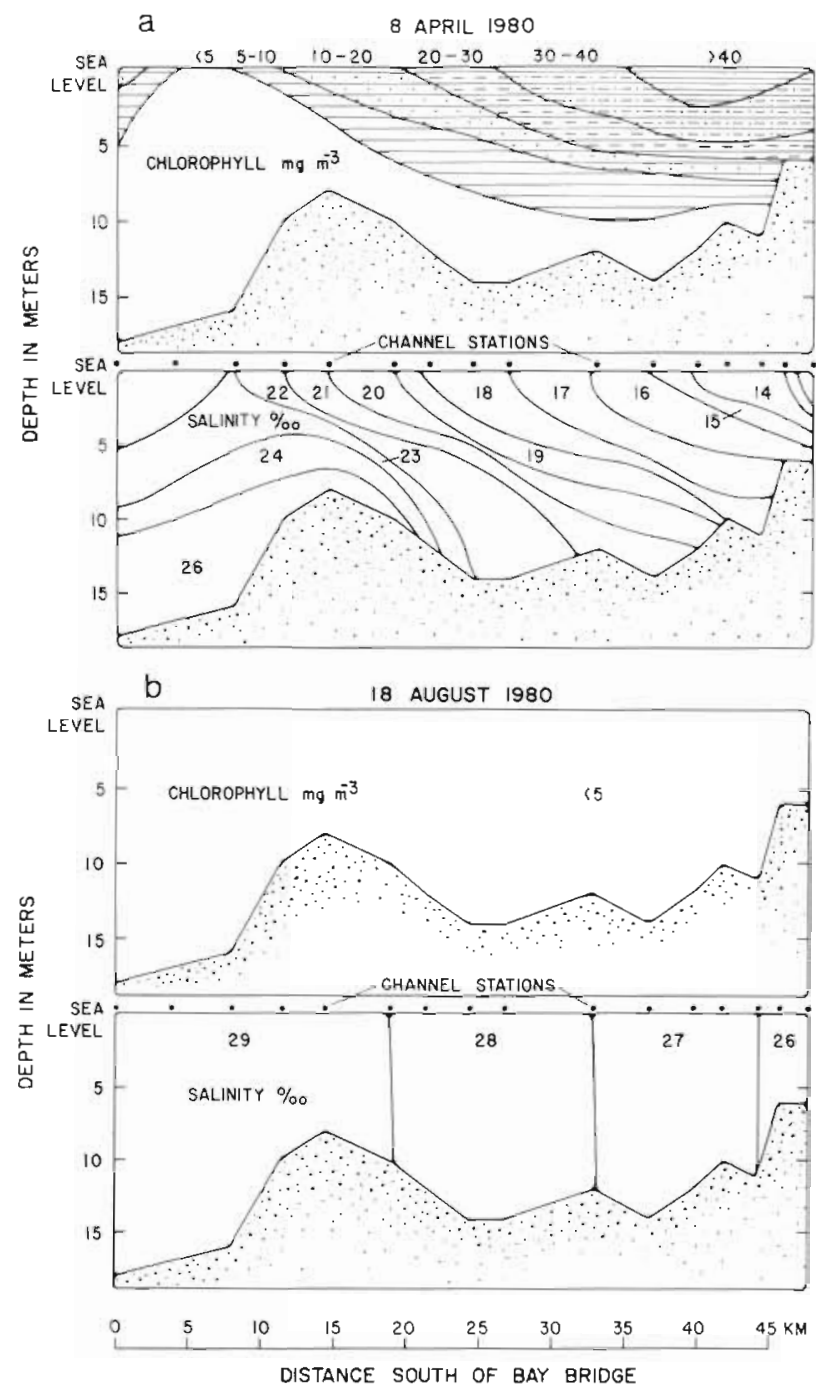

Fig. 5. Vertical contours of chlorophyll a and salinity along the South Bay channel: (a) during the brief spring period of salinity stratification; (b) during the remainder of the year

concentration was restricted to the surface layer in the channel (Fig. 5a). Throughout the summer-fall-winter period of low phytoplankton biomass, the South Bay was well mixed (e. g. Fig. 5b). A spring bloom, followed by low phytoplankton biomass, was also observed in South Bay during 1978 and 1979.

Seasonal changes in mean phytoplankton and zooplankton biomass (as carbon) are shown for the channel and eastern shoals in Fig. 6a and 6d. Temporal patterns were similar in the channel and shoals, although phytoplankton biomass was higher in the shoals during April. Zooplankton biomass also peaked during spring, and total zooplankton biomass was roughly $10 \%$ of calculated phytoplankton biomass. The second increase in zooplankton biomass (October-November) has not been observed in previous 
years. The zooplankton community was dominated by Acartia, which constituted $68 \%$ of the annual mean zooplankton biomass.

The mean specific growth rate of phytoplankton varied from 0.0 to $0.46 \mathrm{~d}^{-1}$ in the channel (Fig. 6c) and from 0.11 to $1.11 \mathrm{~d}^{-1}$ in the shoals (Fig. 6f). Calculated growth rate was generally highest in August-September. In the channel, calculated zooplankton grazing led to substantial reductions in net rate of phytoplankton population growth, particularly during fallwinter (Fig. 6c). In the shoals, however, zooplankton grazing was a negligible sink for phytoplankton production (Fig. 6f). Calculated transport rate was usually positive (due, in part, to a net influx of chlorophyll into central South Bay from the boundaries) and was always of smaller magnitude than specific growth rate in the shoals. Calculated net rates of population growth were usually positive and were very high in the shoals from May through October (Fig. 6e).

\section{DISCUSSION}

Calculated rates of phytoplankton population growth have little relationship to observed population dynamics in South Bay. Calculated rates of growth are consistent with changing phytoplankton biomass only in April of 1980 (i. e. Equation 1 predicts a pulse in April). However, Equation 1 also predicts large increases in phytoplankton biomass in the channel during other times of the year (Fig. 6b). Deviations between calculated and observed rates of population growth are even larger in the shoals (Fig. 6e), where the population is predicted to grow continuously and at very high rates during summer (the mean specific growth rate of $0.8 \mathrm{~d}^{-1}$ in summer corresponds to 1.2 doublings $\mathrm{d}^{-1}$ ).

Discrepancies between observed and calculated rates of population change result from either (1) inadequacy of the model (i.e. failure of Equation 1 to repre-
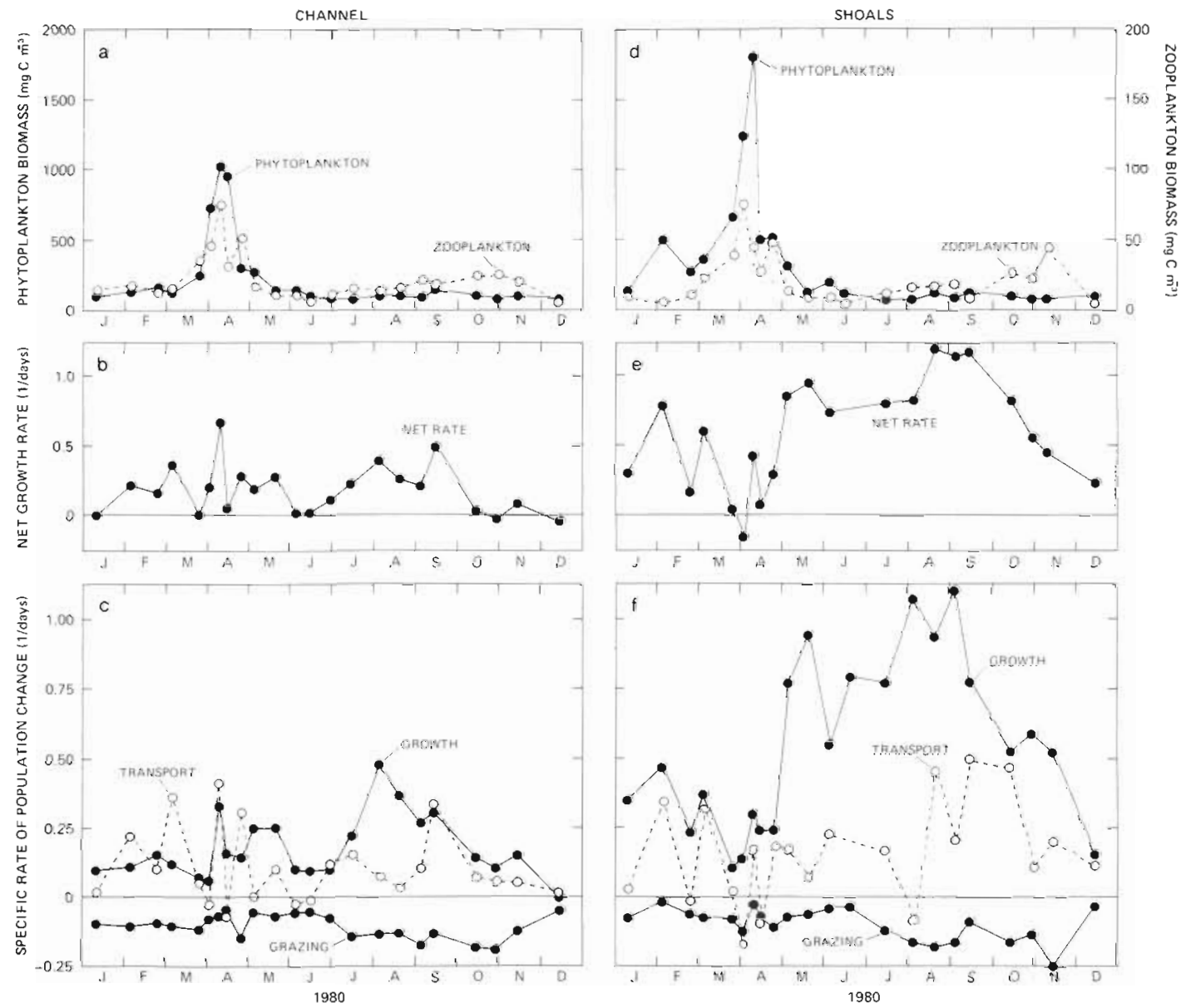

Fig. 6. Mean phytoplankton biomass (assuming a C:CL ratio of 49) and zooplankton biomass in the channel and eastern shoals of South Bay during 1980; phytoplankton biomass is the mean of surface values measured at Stations 23 to 31 (a) or 118 to 126 and 156 to 170 (d); zooplankton biomass is the mean of all samples collected at Stations 24, 27, 30 (a) or 118, 126, 156, 162, 168 (d). Net rate of phytoplankton population growth in the channel (b) and shoals (e). Calculated specific growth rate, transport rate, and zooplankton grazing rate in the channel (c) and shoals (f) 
sent all processes that affect phytoplankton biomass), or (2) large errors in the calculation of process rates (i. e. overestimates of net population growth rate), particularly during summer. Specific growth rate is calculated from $C L, I_{O^{\prime}} \varepsilon, H, P_{M^{\prime}}^{B} a$, and $r^{B}$ which are measured with reasonable accuracy, and the phytoplankton $C: C L$ ratio which is measured with relatively large errors. The assumed constant $\mathrm{C}: \mathrm{CL}$ ratio used here (49) is close to ratios measured in the laboratory on phytoplankton isolated from San Francisco Bay (P. J. Alexander, unpubl.). Moreover, individual estimates of C: $C L$ from phytoplankton samples were lowest $(<50)$ during the summer. Hence, phytoplankton biomass as carbon may be overestimated and specific growth rate underestimated (Equation 8) during summer.

Photosynthetic parameters measured at the 2 key stations were apparently representative of the phytoplankton community within the study area. On the 6 dates when $P_{M}^{B}$ was measured baywide, values from Stations 27 and 162 usually agreed within $25 \%$ of mean values measured at the other channel and shoal sites, and they never deviated by more than $50 \%$ of the mean. Temporal variations in $P_{M^{\prime}}^{B} a$, and $r^{B}$ were surprisingly similar between the channel and shoal populations (Cole et al., 1982). Equations (6) and (8) give valid estimates of $\int P$ and $\mu$ only when phytoplankton are vertically mixed with sufficient velocity to preclude depth variations in biomass or physiological condition. This assumption is reasonable during most of the year when vertical variations in density and chlorophyll are absent. From distributions of radon-222, Hammond and Fuller (1979) inferred that the South Bay channel completely mixes vertically at least twice daily. Therefore, none of the assumptions inherent in the calculation of specific growth rate is grossly violated.

Maximum rates of zooplankton ingestion $(3 \mathrm{mg} \mathrm{C}$ $\mathrm{mg}^{-1} \mathrm{C} \mathrm{d}^{-1}$ for nauplii) used in Equation 11 are at the upper end of reported ingestion rates in the literature. However, Deason (1980) calculated high maximum ingestion rates (up to $6.6 \mathrm{mg} \mathrm{C} \mathrm{mg}^{-1} \mathrm{C} \mathrm{d}^{-1}$ ) by Acartia in Narragansett Bay. If Acartia actually ingest phytoplankton biomass this rapidly in San Francisco Bay, then calculated grazing rates may be underestimated here by a factor of 2. Still, a doubling of $G_{z}$ will not substantially reduce the calculated rate of phytoplankton growth over the shoals (Fig. 6e). Moreover, grazing rate calculations assume that zooplankton ingest only phytoplankton. Measurements of total particulate organic carbon $\left(\simeq 500 \mathrm{mg} \mathrm{C} \mathrm{m}{ }^{-3}\right.$; Conomos et al., 1979) indicate that phytoplankton constitute less than half the suspended organic matter in South Bay during summer. If zooplankton derive part of their ration from detritus, then $\mathrm{G}_{\mathrm{z}}$ may be overestimated here. Microzooplankton may be important grazers in South Bay, but use of a $20-\mu \mathrm{m}$ net does not produce a significant increase in the numbers of organisms compared to the 64-mum net (A. Hutchinson, pers. comm.), and nonpigmented flagellates or ciliates are not apparent when enumerating phytoplankton (R. L. J. Wong, pers. comm.).

Our understanding of circulation in South San Francisco Bay is primitive, and estimates of the transport component of net rate of population change (Figs. 6c, f) are certainly in error. Equation 1 implies that (1) nontidal advection is slow, (2) the dispersion coefficient is constant spatially and temporally, (3) vertical components of circulation and mixing are trivial, and (4) lateral transport is zero. Although these assumptions are, to different degrees, invalid, Equations 3 and 4 should estimate the significance of transport within an order of magnitude since Equation 1 successfully describes the longitudinal flux of salt in South Bay and the movement of dye in a physical model of the Bay. The assumed constant value of $D\left(10^{6} \mathrm{~cm}^{2} \mathrm{~s}^{-1}\right)$ is the highest value measured by Glenne and Selleck (1969), and calculated transport rates probably represent upper bounds on the rate at which transport processes influence phytoplankton population dynamics. Actual rates of dispersive transport probably vary with springneap variations in tidal current velocity, and probably are slower over the shoals (where calculated tidal currents are slower; Cheng, 1982) than in the deeper channel. Moreover, tidal mixing does occur between the channel and shoals and realistic treatment of dispersion requires a two-dimensional model. An initial approach to the transport problem included an advective component (assuming northerly flow over the shoals and southerly flow in the channel, with a constant speed of $4 \mathrm{~cm} \mathrm{~s}^{-1}$ ). In this case the calculated advective flux often canceled the dispersive flux, and the estimated transport term was usually smaller than values reported here, and occasionally was negative. However, calculated net rate of transport was rarely of sufficient magnitude to balance specific growth rate during summer. Although transport processes are treated here in a simple manner, it is unlikely that tidal mixing or residual circulation control phytoplankton biomass during summer. The time scale of phytoplankton population growth is on the order of a day, whereas the time scale of water replacement in South Bay by tidal and nontidal currents is much longer.

It appears, therefore, that planktonic algae divide about once a day in the shoals and about once every 2 to $5 \mathrm{~d}$ in the channel (during summer), and that transport losses and losses to zooplankton are not sufficient to preclude population growth of phytoplankton. Therefore, some other process must control phytoplankton biomass in South Bay. Nichols (1979) demonstrated a high biomass (up to $10^{3} \mathrm{~g}$ wet weight $\mathrm{m}^{-2}$ ) of 
benthic invertebrates in South San Francisco Bay, and it is of interest to determine whether the bottom community has the potential to control phytoplankton biomass. Within the benthic community, 3 suspensionfeeding bivalves are abundant (Musculus senhousia, Tapes japonica, Gemma gemma). Thompson (pers. comm.) calculated the mean abundance and wet weight of bivalves from samples collected at 11 sites in South Bay during February and August 1973, and these values were used to calculate community filtration rate. Dry weight was estimated as $5 \%$ of wet weight (Lie, 1968), and filtration rate of each species was estimated as a power function of body weight W ( $g$ dry weight animal ${ }^{-1}$ ):

$$
F\left(1 \text { animal }{ }^{-1} \mathrm{~d}^{-1}\right)=168 W^{0.67}
$$

which represents the mean filtration rate of 5 suspension-feeding bivalves measured by Møhlenberg and Riisgård (1979). Filtration rate of each species was multiplied by mean population density to give population filtration rates, and these were summed to estimate total community filtration rate in February and August (Table 2). These 3 bivalves alone potentially filter 7.2 to $10.8 \mathrm{~m}^{3} \mathrm{~m}^{-2} \mathrm{~d}^{-1}$. Since the mean depth of South Bay is $6 \mathrm{~m}$, the bivalves can filter a volume equivalent to 1.2 to 1.8 times the South Bay volume daily.

As with other processes, it is difficult to extrapolate the rate of filtration measured under controlled laboratory conditions to a natural system. For example, the effective removal rate of phytoplankton by infauna depends upon (1) the rate of vertical mixing in the water column, (2) the degree to which turbulent mixing decreases near the bottom boundary, and (3) the thickness of the zone above the bottom where bivalve siphons can collect water. If water replacement in this zone is slow relative to pumping by bivalves, then the effective rate of particle removal in a water column is less than predicted here. The presence of suspended sediment influences filtration by bivalves, although no consistent trend is evident from the published literature. Kiørboe et al. (1981) found that a silt suspension of $20 \mathrm{mg}^{-1}$ inhibits clearance by Mytilus edulis, whereas Chiba and Ohshima (1957) reported that pumping of marine bivalves (including Venerupis = Tapes) is only slightly reduced in the presence of a dense suspension (500 $\left.\mathrm{mg} \mathrm{l}^{-1}\right)$ of bentonite. The clearance rate of bivalves also varies with temperature. For example, Walne (1972) showed that the filtration rate of Venerupis increases almost 5-fold as temperature increases from 10 to $20^{\circ} \mathrm{C}$. Equation 12 predicts filtration rate of animals at 10 to $13^{\circ} \mathrm{C}$, and probably underestimates filtration rate of animals in South Bay during summer. Because of these sources of variability and the heterogeneous distribution of benthos, it is impossible to estimate accurately the rate of phytoplankton removal by benthos. However, the rates predicted here are an order of magnitude greater than mean calculated rates of transport or zooplankton grazing, and they are of sufficient magnitude to control phytoplankton biomass.

High grazing pressure by infauna may partly explain the spring bloom during periods of stratification (Fig. 5a) since algal cells retained in a surface layer are not subjected to this grazing, and the surface population can grow rapidly. The distribution of benthic invertebrates may also explain differences in phytoplankton population dynamics between northern and southern San Francisco Bay. Suspension-feeding bivalves are less abundant in the northern San Francisco Bay estuary, presumably because of high suspended sediment loads and large seasonal variations in salinity (J. K.

Table 2. Mean population density, mean body weight, and calculated filtration rate of 3 bivalves in South San Francisco Bay during February and August

\begin{tabular}{|c|c|c|c|c|}
\hline \multirow[b]{2}{*}{ Bivalve } & \multicolumn{3}{|c|}{ Individual } & \multirow{2}{*}{$\begin{array}{c}\text { Population } \\
\begin{array}{c}\text { Filtration rate } \\
\left(\mathrm{m}^{3} \mathrm{~m}^{-2} \mathrm{~d}^{-1}\right)\end{array}\end{array}$} \\
\hline & $\begin{array}{c}\text { Density } \\
\text { (animals } \mathrm{m}^{-2} \text { ) }\end{array}$ & $\begin{array}{c}\text { Dry weight } \\
\left.\text { (mg animal }^{-1}\right)\end{array}$ & $\begin{array}{l}\text { Filtration rate } \\
\left(1 \text { animal }{ }^{-1} \mathrm{~d}^{-1}\right)\end{array}$ & \\
\hline & \multicolumn{4}{|c|}{ February } \\
\hline Gemma gemma & 1000 & 0.4 & 0.9 & 0.9 \\
\hline Musculus senhousia & 350 & 12.0 & 8.7 & 3.0 \\
\hline \multirow[t]{3}{*}{ Tapes japonica } & 360 & 39.5 & 19.3 & 6.9 \\
\hline & & & Total & $\overline{10.8}$ \\
\hline & \multicolumn{4}{|c|}{ August } \\
\hline Gemma gemma & 2700 & 0.2 & 0.5 & 1.2 \\
\hline Musculus senhousia & 170 & 22.0 & 13.0 & 2.2 \\
\hline \multirow[t]{2}{*}{ Tapes japonica } & 250 & 27.5 & 15.1 & 3.8 \\
\hline & & & Total & $\overline{7.2}$ \\
\hline
\end{tabular}


Thompson, pers. comm.). This may explain why phytoplankton biomass is higher in the northern reach (chlorophyll a often exceeds $40 \mathrm{mg} \mathrm{m}^{-3}$ during summer), even though specific growth rates there are low. Differences also exist in composition of the phytoplankton communities of northern and southern San Francisco Bay. During summer, phytoplankton biomass in northern San Francisco Bay is typically dominated by neritic diatoms, while biomass of South Bay is dominated by microflagellates or small $(<10 \mu \mathrm{m})$ diatoms. If benthic grazing exerts a primary control on South Bay phytoplankton, this process may select against forms that sink rapidly (i. e. large diatoms).

Although circumstantial in nature, available evidence is consistent with the hypothesis that benthos control phytoplankton biomass in South San Francisco Bay. If this is true, then the South Bay behaves like a large aquaculture system (Mann and Ryther, 1977) where sewage-derived wastes are converted to algal biomass and then molluscan biomass. The stability of this ecosystem is unknown, and it is important to recognize the potential for algal blooms in South Bay if the benthic community is selectively perturbed. The benthos obviously are a major component of the food web of South Bay since most primary production in the water column is apparently consumed directly by bottom organisms. This may explain the preponderance of demersal fish (sharks, rays) in South Bay (Herald and Ripley, 1951), and suggests a food chain that may be common in shallow waters: phytoplankton (microflagellates) $\rightarrow$ clams (or polychaetes) $\rightarrow$ bottom-feeding fish. Others (e.g. Kremer and Nixon, 1978; van der Eijk, 1979; Dame et al., 1980) have speculated about the potential control of algal populations by bottom organisms, and it is necessary now to quantify the flux of organic matter from the water column to benthos, and to determine whether this process is of general significance in shallow marine systems.

Finally, if benthic suspension-feeders 'process' the water of South Bay once daily, they may also control other dynamic features. For example, Santschi et al. (1982) believe that benthic suspension feeders accelerate the flux of particles and trace metals from the water column to the sediments in Narragansett Bay. Measurement of benthic community filtration may also further our understanding of nutrient-cycling, sediment dynamics, and trace-metal partitioning in the South Bay and other shallow waters.

Acknowledgements. Results presented here were from the collaborative efforts of Andrea Alpine, Brian Cole, Anne Hutchinson, and Raymond Wong. Janet Thompson kindly provided data on the benthic invertebrates of South Bay. Frederic Nichols, Roy Walters, and John Cullen offered valuable reviews of the original manuscript

\section{LITERATURE CITED}

Alpine, A. E., Cloern, J. E., Cole, B. E. (1981). Plankton studies in San Francisco Bay. I. Chlorophyll distributions and hydrographic properties of the San Francisco Bay estuary. July 1977 - December 1979. U.S. Geological Survey, Open-File Report 81-213

Carpenter, J. H., Pritchard, D. W., Whaley, R. C. (1970). Observations of eutrophication and nutrient cycles in some coastal plain estuaries. In: Eutrophication: causes, consequences, corrections. Proceedings of International Symposium on Eutrophication. National Academy of Sciences, Washington, D. C., pp. 210-221

Chalker, B. E. (1980). Modelling light saturation curves for photosynthesis: an exponential function. J. theor. Biol. 118: 205-215

Cheng, R. T. (1982). Modeling of tidal and residual circulation in San Francisco Bay, California. In: MacArthur, R. C., Gee, D. M., Feldman, A. D. (eds.) 2-Dimensional flow modeling. Proceedings of First National U.S. Army Corps of Engineers - Sponsored Seminar on 2-dimensional flow modeling (7-9 July, 1981). Hydrologic Engineering Center, U.S. Army Corps of Engineers, Davis, Calif., pp. 172-186

Chiba, K., Ohshima, Y. (1957). Effect of suspending particles on pumping and feeding of marine bivalves, especially the Japanese little neck clam (in Japanese, English summary). Bull. Jap. Soc. scient. Fish. 23: 348-354

Cloern, J. E. (1979). Phytoplankton ecology of the San Francisco Bay system: the status of our current understanding. In: Conomos, T. J. (ed.) San Francisco Bay: the urbanized estuary. Pacific Division, AAAS, San Francisco, pp. $247-264$

Cloern, J. E., Oremland, R. S. (1982). Chemistry and microbiology of a sewage spill in South San Francisco Bay. Estuaries, in press

Cole, B. E., Cloern, J. E., Alpine, A. E. (1982). Primary production by three phytoplankton size fractions in South San Francisco Bay, U.S.A. (in prep.)

Conomos, T. J. (1979). Properties and circulation of San Francisco Bay waters. In: Conomos, T. J. (ed.) San Francisco Bay: the urbanized estuary. Pacific Division, AAAS, San Francisco, pp. 47-84

Conomos, T J., Smith, R. E., Peterson, D. H., Hager, S. W., Schemel, L. E. (1979). Processes affecting seasonal distributions of water properties in the San Francisco Bay estuarine system. In: Conomos, T J. (ed.) San Francisco Bay: the urbanized estuary. Pacific Division, AAAS, San Francisco, pp. 115-142

Conover, R. J. (1956). Oceanography of Long Island Sound, 1952-1954. VI. Biology of Acartia clausi and A. tonsa. Bull. Bingham. oceanogr. Coll. 15: 156-233

Dame, R., Zingmark, R., Stevenson, H., Nelson, D. (1980). Filter feeder coupling between the estuarine water column and benthic subsystems. In: Kennedy, V.S. (ed.) Estuarine perspectives. Academic Press, New York, pp. $521-526$

Deason, E. E. (1980). Grazing of Acartia hudsonica (A. clausi) on Skeletonema costatum in Narragansett Bay (USA): influence of food concentration and temperature. Mar Biol. 60: 101-113

Fischer, H. B., Kirkland, W. B., Jr (1978). Flushing of South San Francisco Bay. Results of dye concentration measurements in the Bay-Delta physical model. Report HBF-78/01, Hugo B. Fischer, Inc, Berkeley, Calif.

Flemer, D. A. (1972). Primary production in the Chesapeake Bay. Chesapeake Sci. 13 (Suppl.): 144-149 
Frost, B. W (1972). Effects of size and concentration of food particles on the feeding behavior of the marine planktonic copepod Calanus pacificus. Limnol. Oceanogr. 17: 805-815

Gamble, J. C. (1978). Copepod grazing during a declining spring bloom in the northern North Sea. Mar. Biol. 49: 303-315

Glenne, B., Selleck، R. E. (1969). Longitudinal estuarine diffusion in San Francisco Bay, California. Wat. Res. 3: 1-20

Hammond, D. E., Fuller, C. (1979). The use of radon-222 to estimate benthic exchange and atmospheric exchange rates in San Francisco Bay. In: Conomos, T. J. (ed.) San Francisco Bay: the urbanized estuary. Pacific Division, AAAS, San Francisco, pp. 213-230

Hargrave, B. T., Geen, G. H. (1970). Effects of copepod grazing on two natural phytoplankton populations. J. Fish. Res. Bd Can. 27: 1395-1403

Harris, R. P., Paffenhöfer, G.-A. (1976). The effect of food concentration on cumulative ingestion and growth efficiency of two small marine planktonic copepods. J. mar. biol. Ass. U.K. 56: $875-888$

Heinle, D. R., Flemer, D. A., Huff, R. T., Sulkin, S. T., Ulanowicz, R. E. (1979). Effects of perturbations on estuarine microcosms. In: Dame, R. F. (ed.) Marshestuarine systems simulation. University of South Carolina Press, Columbia, S.C.

Herald, E. S., Ripley, W. E. (1951). The relative abundance of sharks and bat stingrays in San Francisco Bay. Calif. Fish Game 37: 315-329

Hobbie, J. E., Copeland, B. J., Harrison, W. G. (1972). Nutrients in the Pamlico River estuary, N. C., 1969-1971. OWRR Project No. B-020-NC

Hutchinson, A. (1981). Plankton studies in San Francisco Bay. III. Zooplankton species composition and abundance in the South Bay, 1978-1979. U.S. Geological Survey, OpenFile Report 81-132

Ichimura, S. (1967). Environmental gradient and its relation to primary productivity in Tokyo Bay. Records Oceanogr. Works Japan 9: 115-128

Ikeda, T. (1974). Nutritional ecology of marine zooplankton. Mem. Fac. Fish., Hokkaido Univ. 22: 1-97

Jassby, A. D., Platt, T. (1976). Mathematical formulation of the relationship between photosynthesis and light for phytoplankton. Limnol. Oceanogr. 21: 540-547

Jaworski, N. S., Lear, D. W., Jr., Villa, O., Jr. (1972). Nutrient management in the Potomac estuary. In: Likens, G. E. (ed.) Nutrients and eutrophication: the limiting-nutrient controversy. Am. Soc. Limnol. Oceanogr., Spec. Symp., Vol. 1, pp. $246-273$

Ketchum, B. H. (1970). Eutrophication in estuaries. In: Eutrophication: causes, consequences, correctives. Proceedings of International Symposium on Eutrophication. National Academy of Sciences, Washington, D. C. pp. $197-209$

Kiørboe, T., Møhlenberg, F., Nøhr, O. (1981). Effect of suspended bottom material on growth and energetics in Mytilus edulis. Mar. Biol. 61: 283-288

Kremer, J. N., Nixon, S. W. (1978). A coastal marine ecosystem: simulation and analysis, Springer-Verlag, New York

Lenz, J. (1977). Seston and its main components. In: Rheinheimer, G. (ed.) Microbial ecology of a brackish water environment. Springer-Verlag, New York, pp. $37-60$

Lie, U. (1968). A quantitative study of benthic infauna in Puget Sound, Washington, USA, in 1963-1964. FiskDir. Skr. Ser. Havunders. 14: 229-556

Loftus, M. E., SubbaRao, D. V., Seliger, H. H. (1972). Growth and dissipation of phytoplankton in Chesapeake Bay. I. Response to a large pulse of rainfall. Chesapeake Sci. 12: 282-299

Lorenzen, C. J. (1967). Determination of chlorophyll and phaeopigments. Spectrophotometric equations. Limnol. Oceanogr. 12: $343-346$

Mann, R., Ryther, J. H. (1977). Growth of six species of bivalve molluscs in a waste-recycling aquaculture system. Aquaculture 11: 231-245

Møhlenberg, F., Riisgård, H. U. (1979). Filtration rate, using a new indirect technique, in thirteen species of suspensionfeeding bivalves. Mar. Biol. 54: 143-147

Mullin, M. M., Brooks, E. R. (1967). Laboratory culture, growth rate, and feeding behavior of a planktonic marine copepod. Limnol. Oceanogr. 12: 657-666

Nichols, F. H. (1979). Natural and anthropogenic influences on benthic community structure in San Francisco Bay. In: Conomos, T. J. (ed.) San Francisco Bay: the urbanized estuary. Pacific Division, AAAS, San Francisco, pp. $409-426$

Nival, P., Nival, S. (1976). Particle retention efficiences of an herbivorous copepod, Acartia clausi (adult and copepodite stages): effects on grazing. Limnol. Oceanogr. 21: 24-38

Paffenhöfer, G.-A. (1971). Grazing and ingestion rates of nauplii, copepodids and adults of the marine planktonic copepod Calanus helgolandicus. Mar. Biol. 11: 286-298

Paffenhofer, G.-A., Knowles, S. C. (1978). Feeding of marine planktonic copepods on mixed phytoplankton. Mar. Biol. 48: $143-152$

Parker, J. H., Deudall, I. W., O' Connors, H. B. Jr., Wilson, R. E. (1976). Raritan Bay as a source of ammonium and chlorophyll a for the New York Bight apex. In: Gross, M. G. (ed.) Middle Atlantic Continental Shelf and the New York Bight. Am. Soc. Limnol. Oceanogr., Spec. Symp., Vol. 2, pp. 212-219

Parsons, T. R., LeBrasseur, R. J. (1970). The availability of food to different trophic levels in the marine food chain. In: Steele, J. H. (ed.) Marine food chains. Oliver and Boyd, Edinburgh, pp. 325-343

Peterson, W. T., Miller, C. B., Hutchinson, A. (1979). Zonation and maintenance of copepod populations in the Oregon upwelling zone. Deep Sea Res. 26A: 467-494

Riley, G. A. (1941). Plankton studies. III. Long Island Sound. Bull. Bingham oceanogr. Coll. 3: 1-93

Santschi, P. M., Adler, D., Amdurer, M. (1982). The fate of particles and particle-reactive trace metals in coastal waters: radioisotope studies in microcosms. In: Wong, C. S., Boyle, F., Bruland, K. (eds.) Proceedings of Research Institute on Trace Metals in Sea Water. Plenum Press, London

Schemel, L. A., Dedini, L. A. (1979). A continuous water sampling and multiparameter measurement system for estuaries. U.S. Geological Survey, Open-File Report $79-273$

Schubel, J. R., Cronin, W. B. (1977). Effects of Agnes on the distribution of dissolved oxygen along the main axis of the bay. In: The Chesapeake Research Consortium Inc. The effect of tropical storm Agnes on the Chesapeake Bay estuarine system. The Johns Hopkins University Press, Baltimore, pp. 335-347

Segar, D. A., Berberian, G. A. (1976). Oxygen depletions in the New York Bight apex: causes and consequences. In: Gross, M. G. (ed.) Middle Atlantic Continental Shelf and New York Bight. Am. Soc. Limnol. Oceanogr., Spec. Symp., Vol. 2, 220-239

Strathmann, R. R. (1967). Estimating the organic carbon content of phytoplankton from cell volume or plasma volume. 
Limnol. Oceanogr. 12: 411-418

van der Eijk, M. (1979). The Dutch Wadden Sea. In: Dunbar M. J. (ed.) Marine production mechanisms. Cambridge University Press, Cambridge, pp. 197-228

Van Valkenberg, S. D., Flemer, D. A. (1974). The distribution and productivity of nannoplankton in a temperate estuarine area. Estuar. coast. mar. Sci. 2: 311-322

Vidal, J. (1980). Physioecology of zooplankton. Mar. Biol. 56: $111-211$

Waine, P. R. (1972). The influence of current speed, body size and water temperature on the filtration rate of five species of bivalves. J. mar. biol. Ass. U. K. 52: 345-374
Walters, R. A. (1982). Low frequency variations in San Francisco Bay (in prep.)

Walters, R. A., Cheng, R. T. (1980). Calculations of estuarine residual currents using the finite element method. In: Norrie, D. H. (ed.) Proceedings of the third international conference on finite elements in flow problems. University of Calgary, Calgary, pp. 60-69

Wong, R. L. J., Cloern, J. E. (1981). Plankton studies in San Francisco Bay. II. Phytoplankton abundance and species composition, July 1977-December 1979. U.S. Geological Survey, Open-File Report 81-214

This paper was submitted to the editor; it was accepted for printing on April 16, 1982 